\title{
Mapping Evidence of Impacts of COVID-19 Outbreak on Sexual and Reproductive Health: A Scoping Review
}

\author{
Obasanjo Afolabi Bolarinwa ${ }^{1}\left(\mathbb{0}\right.$, Bright Opoku Ahinkorah $\left.^{2}{ }^{(}\right)$, Abdul-Aziz Seidu ${ }^{3,4}{ }^{\oplus}$, \\ Edward Kwabena Ameyaw 2,5 ${ }^{(0)}$, Balsam Qubais Saeed ${ }^{6}{ }^{(0)}$, John Elvis Hagan Jr. $7,8, * \mathbb{(}$ \\ and Ugochinyere Ijeoma Nwagbara ${ }^{1}$ (i)
}

check for updates

Citation: Bolarinwa, O.A.; Ahinkorah, B.O.; Seidu, A.-A.; Ameyaw, E.K.; Saeed, B.Q.; Hagan, J.E., Jr.; Nwagbara, U.I. Mapping Evidence of Impacts of COVID-19 Outbreak on Sexual and Reproductive Health: A Scoping Review. Healthcare 2021, 9, 436. https://doi.org/10.3390/ healthcare 9040436

Academic Editor: Emanuele Amodio

Received: 15 March 2021

Accepted: 6 April 2021

Published: 8 April 2021

Publisher's Note: MDPI stays neutral with regard to jurisdictional claims in published maps and institutional affiliations.

Copyright: (c) 2021 by the authors. Licensee MDPI, Basel, Switzerland. This article is an open access article distributed under the terms and conditions of the Creative Commons Attribution (CC BY) license (https:/ / creativecommons.org/licenses/by/ $4.0 /)$.
1 Department of Public Health Medicine, School of Nursing and Public Health, University of KwaZulu-Natal, Durban 4041, South Africa; 219098880@stu.ukzn.ac.za (O.A.B.); microugo4real@yahoo.com (U.I.N.)

2 School of Public Health, University of Technology Sydney, Sydney, NSW 2007, Australia; brightahinkorah@gmail.com (B.O.A.); edmeyaw19@gmail.com (E.K.A.)

3 Department of Population and Health, University of Cape Coast, Cape Coast PMB TF0494, Ghana; abdul-aziz.seidu@stu.ucc.edu.gh

4 College of Public Health, Medical and Veterinary Services, James Cook University, Townsville, QLD 4811, Australia

5 L \& E Research Consult, Wa 00233, Upper West Region, Ghana

6 Department of Clinical Sciences, College of Medicine, University of Sharjah, Sharjah 27272, United Arab Emirates; bsaeed@sharjah.ac.ae

7 Department of Health, Physical Education, and Recreation, University of Cape Coast, Cape Coast PMB TF0494, Ghana

8 Neurocognition and Action-Biomechanics-Research Group, Faculty of Psychology and Sport Sciences, Bielefeld University, Postfach 1001 31, 33501 Bielefeld, Germany

* Correspondence: elvis.hagan@ucc.edu.gh

Abstract: Introduction: The emergence of the coronavirus disease 2019 (COVID-19) pandemic has rapidly transformed the pre-existing worldwide sexual and reproductive health environment. The provision and supply of contraceptives, and a wide variety of sexual health, new-born, and maternal health services have been seriously affected. Thus, this scoping review mapped the available evidence on the impacts of the COVID-19 outbreak on sexual and reproductive health. Methods: Arksey and O'Malley's methodological framework guided this scoping review. A search was conducted from the following databases: Embase, PubMed, CINAHL, Scopus, WOS, and AJOL. The preferred reporting items for systematic reviews and meta-analyses (PRISMA) chart and PRISMA extension for scoping reviews (PRISMA-ScR) checklist were used to document the review process. The McMaster critical review checklist was used to determine the quality of the included studies. Thematic analyses were conducted using NVivo version 12. Results: Three studies showed evidence on the impact of COVID-19 and family planning services, six studies reported on maternal and child services and eleven studies reported on sexual health (sexual behavior). Limited access to family planning use, reduction in multiple sexual partnership, decreased transactional sex, and maternal and child services disruption were some impacts reported in the included studies. Conclusion: This study has demonstrated the impacts of COVID-19 on family planning access, multiple sexual partnership, transactional sex, and disruption of maternal and child health services. Interventions that will consider the immediate availability of and access to all sexual and reproductive health services should be prioritized.

Keywords: COVID-19; family planning; maternal and child health services; sexual health; sexual and reproductive health

\section{Introduction}

The emergence of the coronavirus disease 2019 (COVID-19) pandemic has transformed the pre-existing worldwide sexual and reproductive health environment rapidly [1,2]. The 
provision and supply of contraceptives and a wide variety of sexual health, new-born, and maternal health services have been seriously affected or disrupted [3-5].

More than two decades ago, the United Nations at the International Conference on Population and Development (ICPD), held in Cairo, recognized the role of an adequate response to an individual's reproductive health needs as a panacea to universal economic and social development [6]. The gathering further endorsed the equal distribution of family planning and other related sexual and reproductive health services via the primary healthcare system to encourage comprehensive reproductive health care utilization [6]. Therefore, reproductive health implies an individual's ability to have a satisfying and safe sex life and have the capacity and freedom to reproduce at their desire [6], hence the need to provide adequate and friendly access to safe, effective, affordable, and acceptable methods of family planning and health care services of their choice that will increase maternal and child health safety. This concept also includes sexual health, which is considered the enhancement of life and personal relations relating to reproduction and sexually transmitted infections (STIs) [6,7].

Prior to the emergence of COVID-19, adverse sexual and reproductive health outcomes have been a major issue globally, with an estimated 210 million women being exposed to pregnancy complications, and approximately half a million of these women dying between pregnancy and the post-partum period [8]. In addition, about 68000 women die every year from complications of unsafe abortions [9]. In the same vein, 3.3 million infants were stillborn, whilst 3 million babies die in the first week of their life yearly [8]. This is also coupled with more than 340 million new sexually transmitted bacterial and protozoal infections acquired every year [10].

Interestingly, uninterrupted access to sexual and reproductive services has been identified as a remedy to curb these adverse sexual and reproductive health globally and across all socio-demographic characteristics [11-14]. However, the sudden emergence of the COVID19 outbreak and the virus's declaration as a global health concern in the first quarter of the year 2020 led many governments worldwide to enforce country-national lockdowns in order to limit the propagation of the virus [15]. These measures have been documented to have altered sexual and reproductive health (SRH) services around the world [16].

Specifically, SRH services such as family planning supplies [17], sexual health [18], and maternal and child health services $[17,19]$ have been disrupted. To ensure adherence to guidelines prescribed by the World Health Organization (WHO) [20], authors at the Guttmacher Institute and others have opined that the sudden halt in supply of SRH services would lead to an unexpected rise in adverse SRH [17,21,22]. Thus, this study intends to map the evidential impacts of COVID-19 on SRH using a systematic scoping review.

\section{Materials and Method}

\subsection{Study Design}

We performed a scoping review by searching for original articles on the impact of COVID-19 on sexual and reproductive health, which includes family planning services, maternal and child health service, and sexual behavior globally between December 2019 and October 2020 using Arksey and O'Malley's [23] scoping review framework and Levac et al. [24] methodological enhancement for scoping review projects guidelines. We also followed the preferred reporting items for systematic reviews and meta-analyses extension for scoping reviews (PRISMA-ScR) guidelines [25], while the Joanna Briggs Institute checklist [26], the McMaster critical review checklist [27], and the authority, accuracy, coverage, objectivity, date, and significance (AACODS) checklist [28] were used for the assessment of the studies.

The study protocol was registered at the open science framework (OSF) and can be accessed via https:/ /osf.io/9mz6s. 


\subsection{Research Question}

The research question was: what are the impacts of the COVID-19 on sexual and reproductive health in terms of access to family planning, maternal and child health services, and sexual behavior?

In order to effectively answer the research question, we adopted the population, concept, and context (PCC) framework developed by the Joanna Briggs Institute [26] to determine the eligibility of our primary research question, as illustrated in Table 1.

Table 1. Population concept context (PCC) framework for defining the eligibility of the studies for the primary research question.

\begin{tabular}{|c|c|c|}
\hline Criteria & Determinants & Description \\
\hline P-Population & All population & $\begin{array}{l}\text { All people whose sexual and } \\
\text { reproductive health has been impacted } \\
\text { by COVID-19. }\end{array}$ \\
\hline \multirow{3}{*}{ C-Concept } & Family planning services & $\begin{array}{l}\text { This is determined by family planning } \\
\text { service availability to people in any } \\
\text { country. The service includes availability } \\
\text { and access to contraceptive service of } \\
\text { choice during the COVID-19 pandemic. }\end{array}$ \\
\hline & $\begin{array}{c}\text { Maternal and child health } \\
\text { service }\end{array}$ & $\begin{array}{l}\text { This is determined by maternal and child } \\
\text { health service availability to people in } \\
\text { any country. The service includes } \\
\text { availability and access to maternal and } \\
\text { child health services of choice during the } \\
\text { COVID-19 pandemic. }\end{array}$ \\
\hline & Sexual behavior & $\begin{array}{l}\text { This is to determine if there has been any } \\
\text { change in sexual behavior in terms of } \\
\text { engagement in non-use of condom, } \\
\text { multiple sexual partners, or transactional } \\
\text { sex during the COVID-19 pandemic. }\end{array}$ \\
\hline C-Context & All countries & $\begin{array}{l}\text { Any country that reported the impact of } \\
\text { COVID-19 on sexual and reproductive } \\
\text { health between December } 2019 \text { and } \\
\text { October } 2020 \text {. }\end{array}$ \\
\hline
\end{tabular}

\subsection{Data sources and Literature Search}

We conducted a systematic literature search on studies published in peer-reviewed journals and grey literature with a focus on the study's research question. Eight electronic databases were searched, and these were Excerpta Medica dataBASE (Embase), PubMed, Cumulative Index of Nursing and Allied Health Literature (CINAHL), Scopus, Web of Science (WOS), and Africa Journals Online (AJOL). A search was also conducted on the Google Scholar website. They were searched for relevant studies published in English between December 2019 and October 2020 with the following key terms: "Coronavirus 2019" OR "COVID-19" with "Family planning use" "Family planning service" OR "Contraceptive use" "Contraception use" "Maternal health service" "Child health service" and "Sexual behavior".

Boolean terms (AND/OR) were used to separate our keywords. Medical subject headings $(\mathrm{MeSH})$ were also used in the electronic database search. We also searched thoroughly through the reference lists of the included articles to source relevant literature.

\subsection{Study Selection}

We conducted the study selection in three stages. Firstly, we performed a comprehensive title screening from the resources retrieved from the databases mentioned above. Secondly, O.A.B. and B.O.A. excluded studies that did not address the study's research 
question along with all the duplicates. Lastly, all included studies that qualified for abstract and full-text screening were uploaded on Endnote X9 software (Clarivate Analytics, Philadelphia, PA, USA) and screened by two reviewers (A.S. and E.K.A.). Discrepancies between the reviewers at abstract and full-text screening stages were resolved by involving a third screener (A.O.B.) through a discussion.

\subsection{Eligibility Criteria}

\subsubsection{Inclusion Criteria}

The study included qualitative and quantitative peer-reviewed primary studies conducted globally. These include:

- Research articles reporting information regarding the impact of COVID-19 on family planning services, maternal and child health service, and sexual behavior.

- Articles that explored any study design published in peer-reviewed journals addressing the research question.

- Articles published in English.

- Articles published between December 2019 and October 2020.

\subsubsection{Exclusion Criteria}

Articles such as commentaries and editorials were not considered. The review did not include studies that do not report the impact of COVID-19 on family planning, maternal and child health services, and sexual behavior. The review also excluded studies conducted in any language other than English.

\subsection{Condition or Domain Being Studied}

This review investigated the impact of coronavirus 2019 on sexual and reproductive health globally.

\subsection{Participants/Population}

The population of interest was all persons who have been affected by COVID-19 whilst accessing any sexual and reproductive health service. Additionally, persons who had experienced any setback in sexual and reproductive health as a result of COVID-19 were included.

\subsection{Data Charting}

The included articles in this study were thoroughly read, and data from these articles were organized into different themes using NVivo 10 (QSR International, Burlington, VT, USA) [29]. The data were extracted with the following headings: author and year, study setting (country), study design, population, mean/age range of participants, percentage of males, percentage of females, family planning service and COVID-19, maternal and child health service and COVID-19, sexual behavior and COVID-19.

\subsection{Quality Assessment of the Included Studies}

The quality assessment was conducted by two external, independent reviewers and was verified by O.A.B. and E.K.A. This was done with the McMaster critical review [27].

\subsection{Collating, Summarizing, and Reporting the Results}

A narrative account of the data extracted from the included studies was analyzed using thematic content analysis. Data were extracted around the following outcomes: impact of COVID-19 on family planning services, impact COVID-19 on maternal and health services, and impact of COVID-19 on sexual behavior. 


\section{Results}

\subsection{Screening Results}

After the database search, this scoping review found two hundred and eighty-nine (289) eligible studies from a total of 1575 articles after title screening and removing duplicates. A total of 47 articles were also excluded following the abstract and 225 after full article screening. Hence, 17 articles were included for analysis. Results of the article screening are presented in Figure 1.
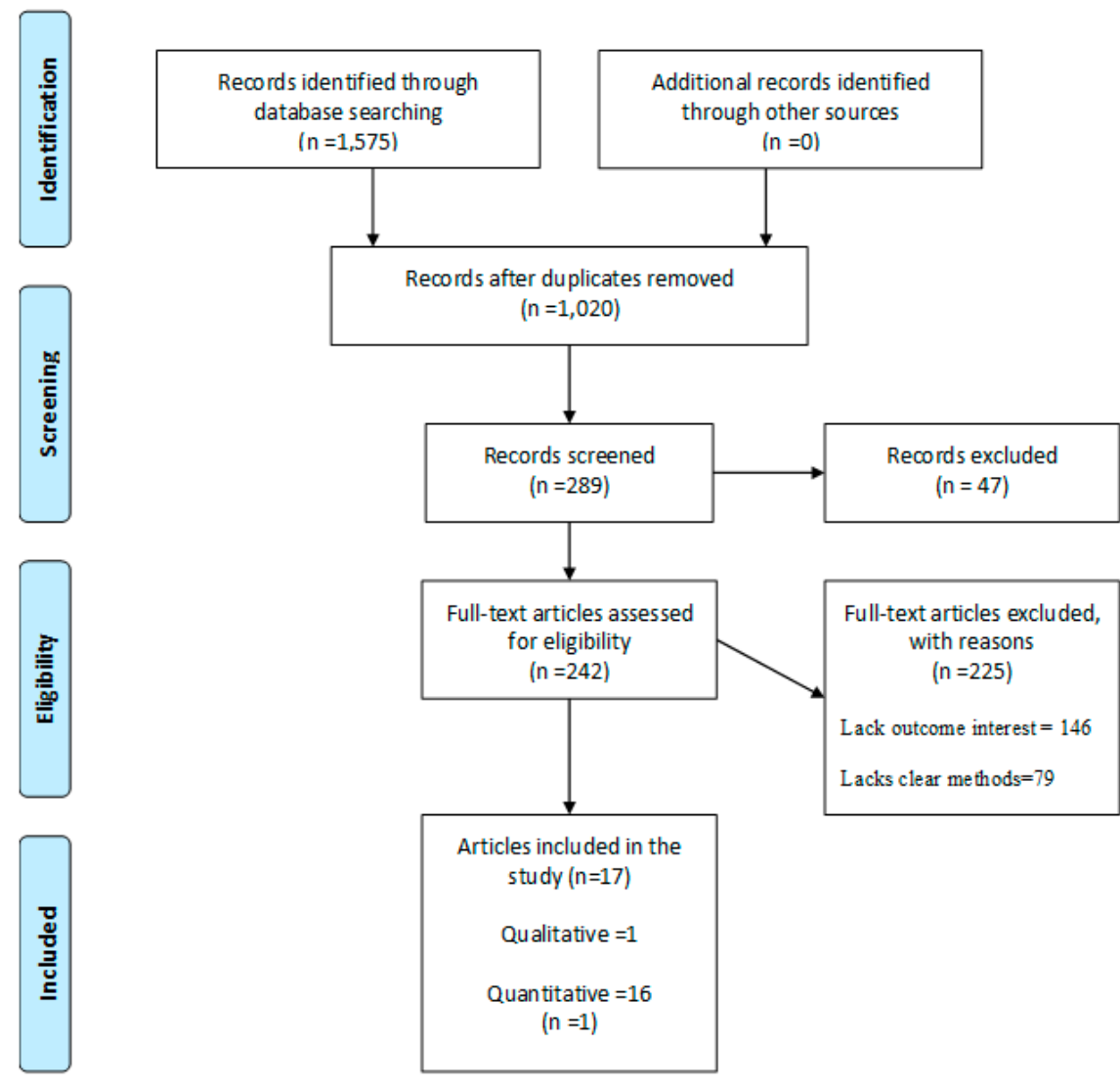

Figure 1. PRISMA flow-chart of the study selection process. (Source: Adapted from Moher et al. [30]).

The preferred report items for systematic and meta-analysis (PRISMA) flow chart for the screening and selection of studies in this review is shown in Figure 1.

\subsection{Characteristics of the Included Studies}

Table 1 shows the characteristics of the included studies. These included studies were conducted in various high income countries (HICs) and low-middle income countries (LMICs) (Figure 2): 23\% of the studies were done in the United Kingdom [31-34], 6\% in Brazil [35], 17\% in the United States [36-38], $6 \%$ in Wales [39], 12\% in Italy [40,41], 6\% in Israel [42], $6 \%$ in the United States, Canada, United Kingdom, Australia, and other countries [43], 6\% in Turkey [44], 6\% in Belgium [45], $6 \%$ in Poland [46], and $6 \%$ in HICs and LMICs [47]. 


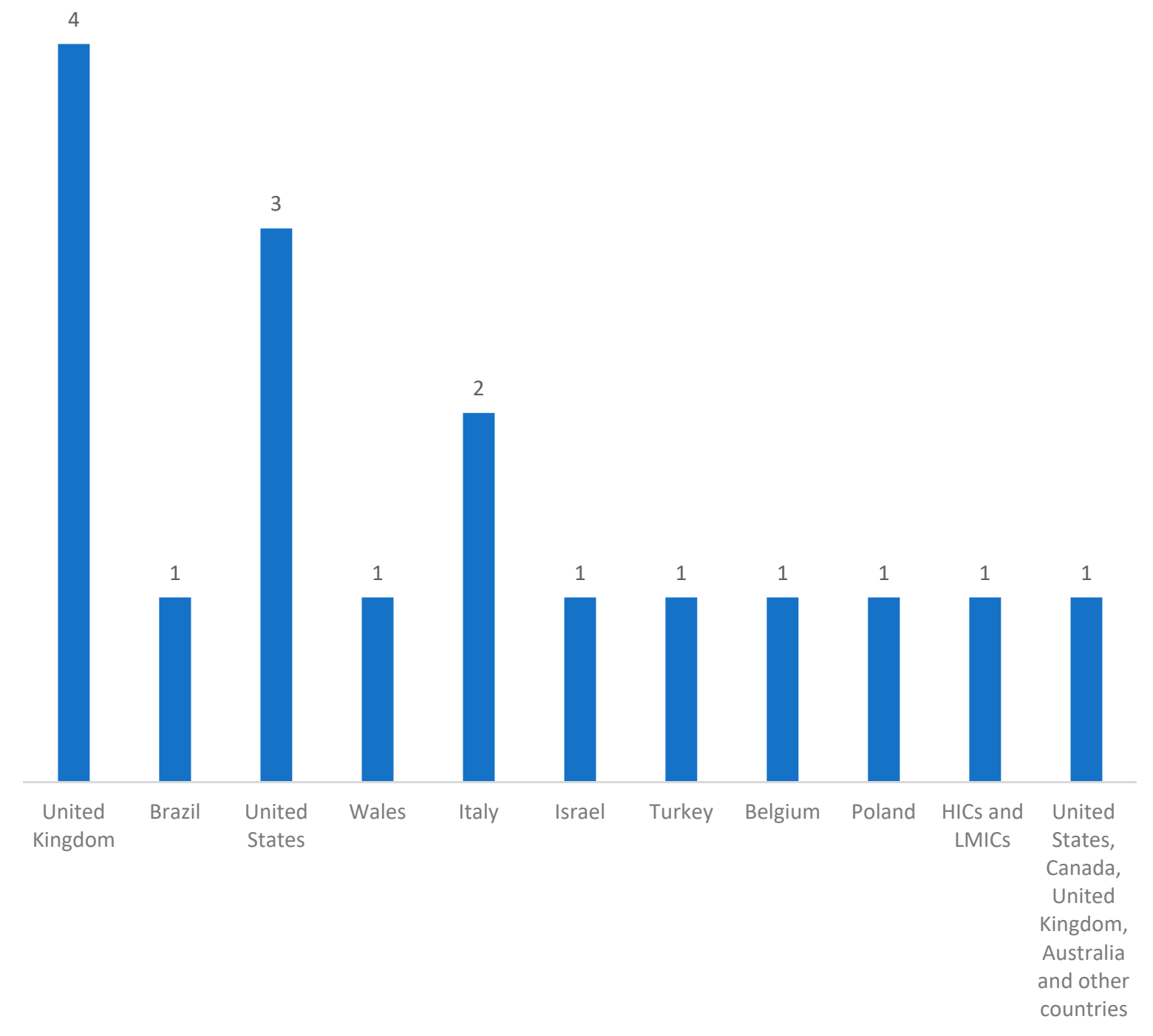

Figure 2. Distribution of the countries represented in the included studies ( $n=17)$.

Three studies showed evidence on the impact of COVID-19 and family planning services [36,40,44], six studies reported on COVID-19 impact on maternal and child services $[31,33,34,44,45,47]$, and eleven studies reported on COVID-19 and sexual behavior $[32,35-39,41-44,46]$.

\subsection{Quality of Evidence from the Included Studies}

All the included studies received a high quality score ranging from $80 \%$ to $100 \%$ during the methodological quality assessment. Overall, the included studies were deemed to have a low chance of bias.

Table 2 below shows that the most common sexual and reproductive health service impacted by the outbreak of COVID-19 was sexual behavior because changes in pattern of sexual behavior were reported in almost all the countries included in the study except in Belgium, with 11 studies reporting unusual sexual behavior during the COVID-19 pandemic [32,35-39,41-44,46]. Contraceptive use or family planning service disruption was reported in the United States [36], Italy [40], and Turkey [44], with 3 studies reporting limited access to contraceptive of choice. Maternal and child health services disruption 
was reported in the United Kingdom thrice [31,33,34], Turkey once [44], Belgium once [45], and once in a study conducted in more than one country [47].

Table 2. Showing common findings in all countries included in the study.

\begin{tabular}{|c|c|c|c|c|c|c|c|c|c|c|}
\hline \multirow[b]{2}{*}{$\begin{array}{l}\text { COVID-19 and SHR } \\
\text { Services }\end{array}$} & \multicolumn{10}{|c|}{ Countries Included in the Study } \\
\hline & $\begin{array}{l}\text { United } \\
\text { King- } \\
\text { dom }\end{array}$ & Brazil & $\begin{array}{l}\text { United } \\
\text { States }\end{array}$ & Wales & Italy & Israel & Turkey & Belgium & Poland & $\begin{array}{l}\text { Multiple } \\
\text { Coun- } \\
\text { tries }\end{array}$ \\
\hline $\begin{array}{l}\text { COVID-19 and family } \\
\text { planning services }\end{array}$ & & & $X^{*}$ & & $X^{*}$ & & $X^{*}$ & & & \\
\hline $\begin{array}{l}\text { COVID-19 and maternal and } \\
\text { child services }\end{array}$ & $X X^{* * *}$ & & & & & & $X X^{*}$ & $X X^{*}$ & & $X X^{*}$ \\
\hline $\begin{array}{l}\text { COVID-19 and sexual } \\
\text { behavior }\end{array}$ & $X X X *$ & $X X X *$ & $X X X^{* * *}$ & $X X X *$ & $X X X *$ & $X X X^{*}$ & $X X X^{*}$ & & $X X X *$ & $X X X^{*}$ \\
\hline
\end{tabular}

Source: Authors, $\mathrm{X}$ represents family planning services were disrupted by COVID-19 outbreak, XX represents maternal and health care services were disrupted by COVID-19 outbreak, XXX represents COVID-19 impacted sexual behavior, * represents number of times study reported any of the SRH by countries.

\subsection{Themes from Included Studies}

\subsubsection{COVID-19 and Family Planning Services}

Four of the seventeen included studies reported on the impact of COVID-19 and family planning services $[36,37,40,44]$. A study conducted in Turkey showed a significant decrease in contraception use during the pandemic compared with the time prior to the pandemic [44].

A cross-sectional study carried out in Italy reported that $50.5 \%$ of single or noncohabiting women had discontinued their short-acting reversible contraception (SARC) method while social distancing due to the COVID-19 pandemic, for non-method-related reasons [40]. However, $46.5 \%$ of the non-cohabiting or single women did not adhere to the social distancing guidelines and continued with their sexual activity resulting in $14.9 \%$ of the women having an unplanned pregnancy and requesting termination [40]. A study conducted on the impact of COVID-19 on men who have sex with men (MSM) in the United States demonstrated that $9.4 \%$ of the participants had less access to condoms, while $5.4 \%$ reported less use of a condom [36].

On the contrary, Sanchez et al. [36] reported that $89.4 \%$ and $92.9 \%$ of the participants had no change in access to or condom use, consecutively, and condom access and usage remained unchanged due to COVID-19 [36] as shown in Table 3. 
Table 3. Summary characteristics of the included studies.

\begin{tabular}{|c|c|c|c|c|c|c|}
\hline Author and Year & $\begin{array}{l}\text { Study Setting } \\
\text { (Country) }\end{array}$ & Study Design & $\begin{array}{c}\text { Population (n) } \\
\text { (Sample Size and Target } \\
\text { Pop) }\end{array}$ & $\begin{array}{l}\text { COVID-19 and Family } \\
\text { Planning Services }\end{array}$ & $\begin{array}{l}\text { COVID-19 and Maternal and } \\
\text { Child Services }\end{array}$ & $\begin{array}{l}\text { COVID-19 and Sexual } \\
\text { Behavior }\end{array}$ \\
\hline $\begin{array}{l}\text { Babu Karavadra et al. } \\
\text { and } 2020 \text { [31] }\end{array}$ & United Kingdom & $\begin{array}{l}\text { Cross-sectional (Web } \\
\text { survey) }\end{array}$ & $\begin{array}{l}\text { Women who were pregnant } \\
\text { or delivered during } \\
\text { COVID-19, } \mathrm{n}=1451\end{array}$ & & $\begin{array}{l}\text { - } 62 \% \text { felt lack of } \\
\text { interpersonal care. } \\
14 \% \text { cannot express } \\
\text { themselves well over the } \\
\text { phone. } \\
2 \% \text { had mobile issues and } \\
\text { could not access maternal } \\
\text { healthcare services. } \\
12 \% \text { could not attend } \\
\text { routine scan } \\
\text { appointments due to fears } \\
\text { about contracting } \\
\text { COVID-19. } \\
\text { 18\% felt neglected by } \\
\text { health workers. }\end{array}$ & \\
\hline $\begin{array}{l}\text { Thiago S. Torres et al. } \\
\text { and } 2020 \text { [35] }\end{array}$ & Brazil & $\begin{array}{l}\text { Cross-sectional } \\
\text { (Web-survey) }\end{array}$ & $\mathrm{n}=3486$ among cismen & & & $\begin{array}{ll}- & 24 \% \text { off-PrEP were at } \\
\text { substantial HIV-risk. } & 46.6 \% \text { had access } \\
\text { - } & \text { challenge in picking up } \\
\text { PrEP medication. } \\
\text { - } \quad 28.8 \% \text { had virtual sex. } \\
\text { - } 10.5 \% \text { reported } \\
\text { condomlessreceptive anal } \\
\text { sex with a casual partner. }\end{array}$ \\
\hline $\begin{array}{l}\text { Travis H. Sanchez et al. } \\
\text { and } 2020 \text { [36] }\end{array}$ & United States & $\begin{array}{l}\text { Cross-sectional (Web } \\
\text { survey) }\end{array}$ & $\begin{array}{l}\text { Men who have sex with } \\
\text { men } \mathrm{n}=1051\end{array}$ & $\begin{array}{l}\text { - } \quad 9.4 \% \text { had less access } \\
\text { to condoms. } \\
\text { - } 5.4 \% \text { reported less } \\
\text { use of a condom. }\end{array}$ & & $\begin{array}{ll}\text { - } & 68 \% \text { reported fewer } \\
\text { opportunities in having } \\
\text { sex with a partner. } \\
25.4 \% \text { had less access to } \\
\text { - } \quad \text { HIV /STI testing or } \\
\text { treatment centers. } \\
54.9 \% \text { having trouble } \\
\text { getting PrEP prescription. } \\
\text { - } 54.1 \% \text { having trouble } \\
\text { getting PrEP medication. }\end{array}$ \\
\hline
\end{tabular}


Table 3. Cont

\begin{tabular}{|c|c|c|c|c|c|c|}
\hline Author and Year & $\begin{array}{l}\text { Study Setting } \\
\text { (Country) }\end{array}$ & Study Design & $\begin{array}{c}\text { Population (n) } \\
\text { (Sample Size and Target } \\
\text { Pop) }\end{array}$ & $\begin{array}{l}\text { COVID-19 and Family } \\
\text { Planning Services }\end{array}$ & $\begin{array}{c}\text { COVID-19 and Maternal and } \\
\text { Child Services }\end{array}$ & $\begin{array}{l}\text { COVID-19 and Sexual } \\
\text { Behavior }\end{array}$ \\
\hline $\begin{array}{l}\text { David Gillespie et al. } \\
\text { and } 2020 \text { [39] }\end{array}$ & Wales & $\begin{array}{l}\text { Longitudinal survey } \\
\text { (Web survey) }\end{array}$ & $\begin{array}{l}\text { Participants were } \\
\text { individuals accessing PrEP } \\
\mathrm{n}=56\end{array}$ & & & $\begin{array}{l}\text { - } \quad 20 \% \text { reported condomless } \\
\text { sex. }\end{array}$ \\
\hline $\begin{array}{l}\text { Salvatore Caruso and } \\
2020[40]\end{array}$ & Italy & $\begin{array}{l}\text { Cross-sectional (Web } \\
\text { survey) }\end{array}$ & $\begin{array}{l}\text { Among women known to } \\
\text { be using hormonal } \\
\text { contraceptives, } n=169\end{array}$ & $\begin{array}{l}50.5 \% \text { of } \\
\text { non-cohabiting } \\
\text { women discontinued } \\
\text { SARC use during } \\
\text { social distancing, for } \\
\text { non-method-related } \\
\text { reasons } \\
14.9 \% \text { had an } \\
\text { unplanned } \\
\text { pregnancy. }\end{array}$ & & \\
\hline $\begin{array}{l}\text { Rob Stephenson et al. } \\
\text { and } 2020 \text { [37] }\end{array}$ & United States & $\begin{array}{l}\text { Cross-sectional (Web } \\
\text { survey) }\end{array}$ & $\begin{array}{l}\text { Among gay, bisexual, and } \\
\text { other men who have sex } \\
\text { with men, } \\
n=518\end{array}$ & & & $\begin{array}{l}\text { - } 1.4 \% \text { reported that they } \\
\text { had participated in } \\
\text { transactional sex. } \\
\text { 9\% reported that } \\
\text { COVID-19 had prevented } \\
\text { them from accessing their } \\
\text { PrEP prescriptions. }\end{array}$ \\
\hline $\begin{array}{l}\text { Guy Shilo and Zohar } \\
\text { Mor and } 2020 \text { [42] }\end{array}$ & Israel & $\begin{array}{l}\text { Cross-sectional (Web } \\
\text { survey) }\end{array}$ & $\begin{array}{l}\text { Among men who have sex } \\
\text { with men, } \\
\mathrm{n}=2562\end{array}$ & & & $\begin{array}{l}\text { - } 39.5 \% \text { met new casual sex } \\
\text { partners during this } \\
\text { period. } \\
\text { Only } 3.2 \% \text { could imagine } \\
\text { themselves having sex } \\
\text { with a partner who is } \\
\text { infected with COVID-19 } \\
\text { compared with } 30.1 \% \text { in } \\
\text { case of HIV. } \\
84 \% \text { had had up to } 3 \\
\text { - } \\
\text { sexual partners. } \\
\text { 2.1\% met more than } 10 \\
\text { sexual partners. }\end{array}$ \\
\hline
\end{tabular}


Table 3. Cont

\begin{tabular}{|c|c|c|c|c|c|c|}
\hline Author and Year & $\begin{array}{l}\text { Study Setting } \\
\text { (Country) }\end{array}$ & Study Design & $\begin{array}{c}\text { Population (n) } \\
\text { (Sample Size and Target } \\
\text { Pop) }\end{array}$ & $\begin{array}{l}\text { COVID-19 and Family } \\
\text { Planning Services }\end{array}$ & $\begin{array}{l}\text { COVID-19 and Maternal and } \\
\text { Child Services }\end{array}$ & $\begin{array}{l}\text { COVID-19 and Sexual } \\
\text { Behavior }\end{array}$ \\
\hline $\begin{array}{l}\text { Michele Carlo Schiavi } \\
\text { and } 2020[41]\end{array}$ & Italy & Cross-sectional & $\begin{array}{l}\text { Women of reproductive age, } \\
\mathrm{n}=89\end{array}$ & & & $\begin{array}{l}\text { - } 9 \% \text { of women did not } \\
\text { have sexual intercourse } \\
\text { during the month of } \\
\text { social restriction. } \\
\text { The number of women } \\
\text { who practiced sexual } \\
\text { intercourses four times/ } \\
\text { month, } 4 \text { weeks after the } \\
\text { introduction of the social } \\
\text { distancing measures due } \\
\text { to the COVID-19 } \\
\text { outbreak, decreased from } \\
89(100 \%) \text { to } 52 \text { (58.4\%). } \\
\text { Women who had sexual } \\
\text { intercourse eight } \\
\text { times/month decreased } \\
\text { from } 31(34.8 \%) \text { vs. } 8 \\
(9 \%) .\end{array}$ \\
\hline $\begin{array}{l}\text { Tyrel J. Starks et al. and } \\
2020 \text { [38] }\end{array}$ & United States & Cohort-control design & $\begin{array}{l}\text { Among sexual minority } \\
\text { men, } \mathrm{n}=455\end{array}$ & & & $\begin{array}{l}\text { - The unweighted } \\
\text { probability of reporting } \\
\text { CAS with a casual partner } \\
\text { declined significantly } \\
\text { from } 71.6 \% \text { pre-COVID to } \\
\text { 26.4\% during COVID. }\end{array}$ \\
\hline
\end{tabular}


Table 3. Cont

\begin{tabular}{|c|c|c|c|c|c|c|}
\hline Author and Year & $\begin{array}{l}\text { Study Setting } \\
\text { (Country) }\end{array}$ & Study Design & $\begin{array}{c}\text { Population (n) } \\
\text { (Sample Size and Target } \\
\text { Pop) }\end{array}$ & $\begin{array}{l}\text { COVID-19 and Family } \\
\text { Planning Services }\end{array}$ & $\begin{array}{l}\text { COVID-19 and Maternal and } \\
\text { Child Services }\end{array}$ & $\begin{array}{l}\text { COVID-19 and Sexual } \\
\text { Behavior }\end{array}$ \\
\hline $\begin{array}{l}\text { Justin J. Lehmiller et al. } \\
\text { and } 2020 \text { [43] }\end{array}$ & $\begin{array}{l}\text { United States } 73.4 \% \\
\text { Canada } 6.0 \% \\
\text { United Kingdom } 5.7 \% \\
\text { Australia } 2.4 \% \\
\text { Other countries, } 12.5 \%\end{array}$ & $\begin{array}{l}\text { Cross-sectional (Web } \\
\text { survey) }\end{array}$ & $\begin{array}{l}\text { Among participants } 18 \\
\text { years of age or older, } \\
\mathrm{n}=1559\end{array}$ & & & $\begin{array}{l}\text { - } 43.5 \% \text { reported a decline } \\
\text { in the quality of their sex } \\
\text { life. } \\
20.8 \% \text { of participants } \\
\text { reported masturbating } \\
\text { once per day or more } \\
\text { during the past year, } \\
23.2 \% \text { reported this } \\
\text { frequency since the } \\
\text { pandemic began. }\end{array}$ \\
\hline $\begin{array}{l}\text { Bahar Yuksel, Faruk } \\
\text { Ozgor and } 2020[44]\end{array}$ & Turkey & $\begin{array}{l}\text { Cross-sectional } \\
\text { (Telephone) }\end{array}$ & $\begin{array}{l}\text { Among married patients } \\
\text { who were older than } 18 \\
\text { years and sexually active, } \\
\mathrm{n}=58\end{array}$ & $\begin{array}{l}\text { - Use of contraception } \\
\text { during the pandemic } \\
\text { significantly } \\
\text { decreased compared } \\
\text { with the period } \\
\text { before (10 } \\
\text { participants vs. } 24 \\
\text { participants, } \\
p=0.004) .\end{array}$ & $\begin{array}{l}\text { Before the pandemic, } 19 \\
(32.7 \%) \text { participants } \\
\text { intended to become } \\
\text { pregnant, however } \\
\text { during the pandemic, this } \\
\text { number decreased to } 3 \\
(5.1 \%)(p=0.001) \text {. }\end{array}$ & $\begin{array}{l}\text { Average weekly } \\
\text { frequency of sexual } \\
\text { intercourse was } \\
\text { significantly increased } \\
\text { during the pandemic } \\
\text { compared with the 6-12 } \\
\text { months prior (2.4 vs. } 1.9 ; \\
p=0.001) \text {. }\end{array}$ \\
\hline $\begin{array}{l}\text { Helen I McDonald et al. } \\
\text { and } 2020 \text { [33] }\end{array}$ & United Kingdom & Cross-sectional & $\begin{array}{l}\text { Vaccination among children, } \\
n=67,116\end{array}$ & & $\begin{array}{l}\text { Measles-mumps-rubella } \\
\text { vaccination counts fell } \\
\text { from February 2020, and } \\
\text { in the } 3 \text { weeks after the } \\
\text { introduction of physical } \\
\text { distancing measures were } \\
19.8 \% \text { lower }(95 \% \\
\text { confidence interval: }-20.7 \\
\text { to }-18.9) \text { than the same } \\
\text { period in } 2019 .\end{array}$ & \\
\hline
\end{tabular}


Table 3. Cont

\begin{tabular}{|c|c|c|c|c|c|c|}
\hline Author and Year & $\begin{array}{l}\text { Study Setting } \\
\text { (Country) }\end{array}$ & Study Design & $\begin{array}{c}\text { Population (n) } \\
\text { (Sample Size and Target } \\
\text { Pop) }\end{array}$ & $\begin{array}{l}\text { COVID-19 and Family } \\
\text { Planning Services }\end{array}$ & $\begin{array}{l}\text { COVID-19 and Maternal and } \\
\text { Child Services }\end{array}$ & $\begin{array}{c}\text { COVID-19 and Sexual } \\
\text { Behavior }\end{array}$ \\
\hline & & & & & $\begin{array}{l}\text { There was a general } \\
\text { decrease in hexavalent } \\
\text { vaccinations delivered in } \\
2020 \text { compared with 2019, } \\
\text { but no evidence of an } \\
\text { increase in the rate of } \\
\text { decline with the } \\
\text { introduction of physical } \\
\text { distancing measures. } \\
\text { Counts of both } \\
\text { vaccinations increased in } \\
\text { weeks } 16 \text { and 17, despite } \\
\text { physical distancing } \\
\text { measures remaining in } \\
\text { place. }\end{array}$ & \\
\hline $\begin{array}{l}\text { Michael Ceulemans } \\
\text { et al. and } 2020 \text { [45] }\end{array}$ & Belgium & $\begin{array}{l}\text { Cross-sectional (Web } \\
\text { survey) }\end{array}$ & $\begin{array}{l}2647 \text { pregnant and } 3823 \\
\text { breastfeeding women, } \\
\mathrm{n}=6470\end{array}$ & & $\begin{array}{l}90 \% \text { refuted that the } \\
\text { pandemic affected their } \\
\text { breastfeeding practices, } \\
\text { nor indicated that the } \\
\text { coronavirus was } \\
\text { responsible for } \\
\text { breastfeeding cessation. } \\
86 \% \text { of all pregnant } \\
\text { respondents answered } \\
\text { that their pregnancy was } \\
\text { mainly followed-up by an } \\
\text { obstetrician. } \\
40 \% \text { cited that the } \\
\text { pandemic negatively } \\
\text { influenced the extent of } \\
\text { medical counseling by } \\
\text { medical specialists. } \\
43 \% \text { of the breastfeeding } \\
\text { women reported having } \\
\text { experienced some impact } \\
\text { of the pandemic on the } \\
\text { extent of medical } \\
\text { counseling during the } \\
\text { breastfeeding period. }\end{array}$ & \\
\hline
\end{tabular}


Table 3. Cont

\begin{tabular}{|c|c|c|c|c|c|c|}
\hline Author and Year & $\begin{array}{l}\text { Study Setting } \\
\text { (Country) }\end{array}$ & Study Design & $\begin{array}{c}\text { Population (n) } \\
\text { (Sample Size and Target } \\
\text { Pop) }\end{array}$ & $\begin{array}{l}\text { COVID-19 and Family } \\
\text { Planning Services }\end{array}$ & $\begin{array}{l}\text { COVID-19 and Maternal and } \\
\text { Child Services }\end{array}$ & $\begin{array}{l}\text { COVID-19 and Sexual } \\
\text { Behavior }\end{array}$ \\
\hline & & & & & $\begin{array}{l}\text { 39\% of the breastfeeding } \\
\text { women reported having } \\
\text { experienced the impact of } \\
\text { the pandemic on the } \\
\text { extent of social support } \\
\text { they received during the } \\
\text { breastfeeding period. }\end{array}$ & \\
\hline $\begin{array}{l}\text { Anna Fuchs et al. and } \\
2020 \text { [46] }\end{array}$ & Poland & Cross-sectional & $\begin{array}{l}764 \text { sexually active female } \\
\text { patients and above } 18 \text { years }\end{array}$ & & & $\begin{array}{l}\text { Desire, arousal, } \\
\text { lubrication, orgasm, } \\
\text { satisfaction, and pain } \\
\text { decreased. } \\
\text { The number of women } \\
\text { with sexual dysfunction } \\
\text { (overall FSFI score } 26 \text { or } \\
\text { below) before the } \\
\text { pandemic was } 15.3 \% \text { and } \\
\text { increased to } 34.3 \% \text { during } \\
\text { the total lockdown. }\end{array}$ \\
\hline $\begin{array}{l}\text { James John Ashton et al. } \\
2020 \text { [34] }\end{array}$ & United Kingdom & Cross-sectional & $\begin{array}{l}20 \text { tertiaries } \\
\text { pediatric IBD centers }\end{array}$ & & $\begin{array}{l}\text { Over } 50 \% \text { of children and } \\
\text { young people presenting } \\
\text { with a suspected } \\
\text { diagnosis of IBD were } \\
\text { diagnosed without a } \\
\text { histological diagnosis due } \\
\text { to restrictions placed on } \\
\text { endoscopy at over } 90 \% \text { of } \\
\text { centers across the UK. } \\
\text { A total of } 122 \text { patients } \\
\text { were diagnosed with } \\
\text { confirmed, or presumed } \\
\text { IBD during April } 2020 \text {. Of } \\
\text { these patients, } 53.3 \% \\
\text { (n = 65) were presumed } \\
\text { diagnoses and had not } \\
\text { undergone endoscopic or } \\
\text { histological examination. }\end{array}$ & \\
\hline
\end{tabular}


Table 3. Cont

\begin{tabular}{|c|c|c|c|c|c|c|}
\hline Author and Year & $\begin{array}{l}\text { Study Setting } \\
\text { (Country) }\end{array}$ & Study Design & $\begin{array}{c}\text { Population (n) } \\
\text { (Sample Size and Target } \\
\text { Pop) }\end{array}$ & $\begin{array}{l}\text { COVID-19 and Family } \\
\text { Planning Services }\end{array}$ & $\begin{array}{l}\text { COVID-19 and Maternal and } \\
\text { Child Services }\end{array}$ & $\begin{array}{c}\text { COVID-19 and Sexual } \\
\text { Behavior }\end{array}$ \\
\hline $\begin{array}{l}\text { Anja Saso, Helen } \\
\text { Skirrow and Beate } \\
\text { Kampmann and } 2020 \\
{[47]}\end{array}$ & LMICs and HICs & $\begin{array}{l}\text { Cross-sectional (Web } \\
\text { survey) }\end{array}$ & $\mathrm{n}=48$ & & $\begin{array}{l}\text { - } 50 \% \text { or more reported } \\
\text { issues with vaccine } \\
\text { delivery within their } \\
\text { country. } \\
\text { Lack of access to maternal } \\
\text { and child health services. } \\
\text { Provider issues with } \\
\text { vaccine supply due to } \\
\text { COVID-19. }\end{array}$ & \\
\hline
\end{tabular}




\subsubsection{COVID-19 and Maternal and Child Services}

Six of the included studies reported on the impact of COVID-19 and maternal and child services $[31,33,34,44,45,47]$. A study conducted in the United Kingdom during COVID-19 lockdown showed that $62 \%$ of pregnant women felt a lack of interpersonal care while using virtual consultations, which affected how much information they disclosed to their healthcare workers [31]. It further reported that $14 \%$ of the participants could not express themselves well over the phone, as they believed that discussing sensitive matters over the telephone was inappropriate [31]. Six percent of the pregnant women had experienced a stillbirth prior to the COVID-19 pandemic and thus would have preferred to have a face-to-face consultation with the health worker to reduce anxiety [31]. Due to the fear of contracting COVID-19, 12\% of the participants couldn't attend routine scan appointments [31]. This finding is similar to a study conducted in Belgium, where 53\% of the pregnant women indicated that the coronavirus pandemic influenced their current pregnancy follow-up to some extent [45].

A study conducted in Turkey showed $32.7 \%$ of participants planned to become pregnant before the pandemic, but the number decreased significantly to $5.1 \%$ throughout the pandemic [44]. A study by McDonald et al. [33] on the impact of COVID-19 on childhood vaccinations in England demonstrated a general decrease in hexavalent vaccinations delivered in 2020 compared with 2019 [33]. Measles-mumps-rubella (MMR) vaccination counts fell from February 2020 before the physical distancing measures implemented in response to the COVID-19 epidemic were introduced. In the first 3 weeks of physical distancing, MMR vaccination counts were $19.8 \%$ lower (95\% CI: -20.7 to -18.9 ) than for the same period in 2019 after introducing physical distancing measures [33]. Forty-three percent (43\%) and thirty-nine percent (39\%) of the breastfeeding women reported having experienced some impact of the pandemic on the extent of medical counselling and social support during the breastfeeding period, respectively [45]. More than $90 \%$ of the breastfeeding women refuted that the pandemic affected their breastfeeding practices, nor did they indicate that the coronavirus was responsible for breastfeeding cessation [45]. A study by Saso et al. [47] showed that $50 \%$ or more reported issues with either maternal or infant/toddler vaccine delivery within their country [47]. The lockdown measures reduced access for pregnant women and infants from easily attending antenatal clinics and primary health care centers, respectively [47]. Adjustments to clinics, shortage of staff, lack of personal protective equipment (PPE), and vaccine supply problems were the provider issues reported by most participants [47]. A study conducted in the UK assessing the impact of the COVID-19 pandemic on the diagnosis and management of pediatric inflammatory bowel disease (IBD) showed that over $50 \%$ of children and young people presenting with a suspected diagnosis of IBD were diagnosed without a histological diagnosis due to restrictions placed on endoscopy at over $90 \%$ of centers across the UK [34] as shown in Table 3 above.

\subsubsection{COVID-19 and Sexual Behavior}

Eleven studies reported the impact of COVID-19 and sexual behavior [32,35-39,41-44,46] as shown in Table 3 above. Torres et al. (35) conducted a study on the impact of the COVID-19 pandemic on sexual minority populations in Brazil showing that almost half of participants, $45.4 \%$, abstained from sex during the social distancing period [35]. The majority of participants reported a decreased number of sexual partners during the social distancing period, with more than three quarters $(76.8 \%)$ of respondents mainly finding casual partners online [35]. The study also showed that $28.8 \%$ of participants had virtual sex [35]. A study on the impact of COVID-19 on men who have sex with men across the United States showed that $68 \%$ of participants had fewer opportunities to have sex with a partner due to COVID-19 [36]. Access to human immunodeficiency virus (HIV) and sexually transmitted infections (STI) testing or treatment centers decreased (25.4\%) as a result of the pandemic [36]. Sanchez et al. [36] revealed that $54.9 \%$ of participants had trouble getting a pre-exposure prophylaxis (PrEP) prescription while $54.1 \%$ also had trouble getting PrEP medication [36]. Another study by Stephenson et al. [37] reported 
that COVID-19 prevented a small percentage (9\%) of the men who have sex with men from accessing their PrEP prescriptions [37].

Gillespie et al. [39] revealed that $42 \%$ of participants reported condom-less sex in the period prior to the introduction of social distancing measures and $20 \%$ reported condomless sex afterward [39].

Few participants $(1.4 \%)$ reported that they had participated in transactional sex for the first time during the COVID-19 lockdown [37]. A study conducted in Israel showed that only $3.2 \%$ of the men who have sex with men could imagine themselves having sex with a partner who is infected with COVID-19 compared with $30.1 \%$ in the case of HIV [42]. This is so because they perceive the threat of severe acute respiratory syndrome coronavirus to be greater than that of HIV [42]. During the COVID-19 social-distancing period, 39.5\% of the participants had met a new casual sex partner while most of them, $84 \%$, had up to 3 sexual partners, and $2.1 \%$ met more than 10 sexual partners [42]. A study conducted in Italy on the sexual function and quality of life in reproductive-age women during the social restriction period due to the COVID-19 epidemic revealed that the mean number of sexual intercourses/month decreased significantly from $6.3 \pm 1.9$ to $2.3 \pm 1.8$, and $9 \%$ women did not have sexual intercourse during the month of social restriction [41]. The number of women who practiced sexual intercourse $\geq 4$ /month, 4 weeks after the introduction of the social distancing measures due to the COVID-19 outbreak, decreased from $100 \%$ to $58.4 \%$ [ 41 ], while women who had sexual intercourses $\geq 8 /$ month decreased from $34.8 \%$ to $9 \%$ [41]. Jacob et al. [32] revealed that $40 \%$ of the population reported engaging in sexual activity at least once per week on average, hence were classified as sexually active [32].

The occurrence of sexual activity significantly increased from $33.5 \%$ in people who were self-isolated for $0-5$ days to $47.0 \%$ in those who were self-isolated for $\geq 11$ days [32]. Starks et al. [38] showed that the unweighted probability of reporting condom-less anal sex (CAS) with a casual partner declined significantly from $71.6 \%$ pre-COVID to $26.4 \%$ during COVID [38]. A study on changes in sexual behavior during the COVID-19 pandemic revealed that $43.5 \%$ of participants reported a decline in the quality of their sex life [43]. A small number of participants (20.8\%) reported masturbating once per day or more during the past year. $23.2 \%$ reported this frequency since the pandemic began [43]. A study conducted in Turkey on the effect of the COVID-19 pandemic on female sexual behavior showed that the weekly frequency of sexual intercourse was significantly increased during the pandemic compared with the 6-12 months prior [44]. Fuchs et al. [46] revealed that female sexual function index (FSFI) scores of domains such as desire, arousal, lubrication, orgasm, satisfaction, and pain decreased during the pandemic among Polish women [46]. This finding is similar to another study in Turkey that reported that the three domain scores for arousal, orgasm, and satisfaction also decreased during the pandemic [44]. The number of women with sexual dysfunction (overall FSFI score 26 or below) before the pandemic was $15.3 \%$ and increased to $34.3 \%$ during total lockdown [46].

\section{Discussion}

This review aimed at harnessing evidence on the impact of COVID-19 on sexual and reproductive health. Thus, we mapped the available evidence using a scoping review. The results of our study showed variations in the impact of COVID-19 on sexual and reproductive health globally. Specifically, the review showed that COVID-19 impacted family planning services, sexual behavior, and maternal and child health services.

Our findings on the impact of COVID-19 on family planning services showed discontinuation in family planning's preferred method because of social distancing [40]. The choice of family planning method has always been a sexual and reproductive health issue prior to the pandemic. However, this impact was felt greatly during the COVID-19 pandemic as a result of limited access to preferred choice [40,48].

The study result showed that despite unchanged access to condoms during COVID-19, participants had fewer sexual partners [36]. This change in behavior could be attributed to COVID-19 social distancing guidelines and stay-at-home orders issued by the national 
government $[49,50]$. On the other hand, some studies in this review reported limited access to PrEP prescription and medications [36], less transactional sex, especially among MSM [37] during the COVID-19 outbreak. The implications suggest a need for increased attention from medical caregivers for their patients with sexual behaviors that lead to a higher risk of HIV infections in the coming months and years following the reductions in the pandemic social restrictions.

Other study results showed that a study conducted in Turkey revealed that about $32.7 \%$ of participants planned to become pregnant before the pandemic, but the number significantly decreased to $5.1 \%$ throughout the pandemic, and the rate of contraception use by women significantly also decreased during the pandemic [44]. It could be that the sexual activity of women during the COVID-19 pandemic was largely affected in Turkey, which is in line with a study conducted in Italy that reported less sexual pleasure or desire in women [51].

Lockdown and social distancing guidelines reduced access for pregnant women and infants from easily reaching antenatal clinics and primary health care centers from receiving vaccines and immunizations [47]. There were some differences between participants from low-middle income countries (LMICs) compared to high-income countries (HICs). The barriers identified in LMICs were mainly provider issues, such as cancelled clinic appointments and unavailability of vaccines. In contrast, participants from HICs reported changes in the clinic format, such as setting up telephone or virtual consultations, rather than indefinite cancellation or suspension of services [47].

Despite the social-distancing regulations and the COVID-19 pandemic lockdown, our study reported that casual sex was common among men who were generally younger, single, and less educated [42]. Prior to the COVID-19 pandemic, unmarried persons, younger, and less educated persons were often reported to engage in casual sex, and this behavior has persisted during the COVID-19 pandemic [52-54].

\section{Strengths and Limitations}

An important strength of this study was the exhaustive search for relevant studies for inclusion using different databases. The results of this scoping review followed the PRISMA guidelines, which ensured complete and transparent reporting of this scoping review. The scoping review methodology permitted the inclusion of various study designs and used a systematic approach to identifying relevant studies, charting, and analyzing the outcomes. Despite the strengths mentioned earlier, the following limitations should not be overlooked. This scoping review limited the language of published articles to include only English. This introduced a selection bias and limited retrieval of relevant studies published in other languages.

\section{Conclusions}

This study has demonstrated the impacts of COVID-19 on family planning access, multiple sexual partnerships, transactional sex, and disruption of maternal and child health services. Interventions that will consider all sexual and reproductive health services' immediate availability should be given priority globally.

Author Contributions: O.A.B. developed the study's concept; O.A.B. and B.Q.S. drafted the introduction; U.I.N., J.E.H.J., and O.A.B. wrote the study's results, discussion, and conclusion sections; O.A.B. and E.K.A. drafted the methodology and the abstract. A.-A.S. and B.O.A. extracted the study results. All the authors were involved in the identification and selection of included studies. All authors have read and agreed to the published version of the manuscript.

Funding: The authors sincerely thank Bielefeld University, Germany for providing financial support through the Open Access Publication Fund for the article processing charge.

Institutional Review Board Statement: Not applicable.

Informed Consent Statement: Not applicable. 
Data Availability Statement: Not applicable.

Acknowledgments: We acknowledged the two anonymous independent reviewers for their supports.

Conflicts of Interest: The authors declare no conflict of interest.

$\begin{array}{ll}\text { Abbreviations } & \\ \text { COVID-19 } & \text { Coronavirus Disease 2019 } \\ \text { PRISMA } & \text { Preferred Reporting Items for Systematic Reviews and Meta-analyses } \\ \text { PRISMA-ScR } & \begin{array}{l}\text { Preferred Reporting Items for Systematic Reviews and Meta-Analyses Extension } \\ \text { for Scoping Reviews }\end{array} \\ \text { ICPD } & \text { International Conference on Population and Development } \\ \text { STI } & \text { Sexually Transmitted Infections } \\ \text { AACODS } & \text { Authority, Accuracy, Coverage, Objectivity, Date, and Significance } \\ \text { OSF } & \text { Open Science Framework } \\ \text { PCC } & \text { Population, Concept, and Context } \\ \text { Embase } & \text { Excerpta Medica database } \\ \text { CINAHL } & \text { Cumulative Index of Nursing and Allied Health Literature } \\ \text { WOS } & \text { Web of Science } \\ \text { AJOL } & \text { Africa Journals Online } \\ \text { SARC } & \text { Short-Acting Reversible Contraception } \\ \text { MSM } & \text { Men who have sex with Men } \\ \text { MMR } & \text { Measles-mumps-rubella } \\ \text { IBD } & \text { Inflammatory Bowel Disease } \\ \text { PPE } & \text { Personal Protective Equipment } \\ \text { HIV } & \text { Human Immunodeficiency Virus } \\ \text { CAS } & \text { Condom-less Anal Sex } \\ \text { FSFI } & \text { Female Sexual; Function Index } \\ \text { LMICs } & \text { Low-Middle-Income Countries } \\ \text { HICs } & \text { High Income Countries; PrEP: Pre-Exposure Prophylaxis } \\ & \end{array}$

\section{References}

1. World Health Organization. Coronavirus Disease (COVID-19) and Sexual and Reproductive Health; WHO website: Geneva, Switzaland, 2020.

2. Church, K.; Gassner, J.; Elliott, M. Reproductive health under Covid-19-challenges of responding in a global crisis. Sex. Reprod. Health Matters 2020, 28, 1-3. [CrossRef]

3. Purdy, C. Opinion: How Will COVID-19 Affect Global Access to Contraceptives-And What Can We Do About It? Devex: Washington, DC, USA, 2020.

4. International Planned Parenthood Federation. COVID-19 Pandemic Cuts Access to Sexual and Reproductive Healthcare for Women around the World; IPPF: London, UK, 2020.

5. Li, G.; Tang, D.; Song, B.; Wang, C.; Shen, Q.; Xu, C.; Geng, H.; Wu, H.; He, X.; Cao, Y. Impact of the COVID-19 pandemic on partner relationships and sexual and reproductive health: Cross-sectional, online survey study. J. Med. Internet Res. 2020, 22, 20961. [CrossRef] [PubMed]

6. UN Department for Economic and Social Information and Policy Analysis. Population and Development: Programme of Action Adopted at the International Conference on Population and Development, Cairo, 5-13 September 1994; Department for Economic and Social Information and Policy Analysis: New York, NY, USA, 1995.

7. Fathalla, M.F.; Fathalla, M.M. Sexual and reproductive health: Overview. Int. Encycl. Public Health 2008, 5, 695-705.

8. Glasier, A.; Gülmezoglu, A.M.; Schmid, G.P.; Moreno, C.G.; Van Look, P.F. Sexual and reproductive health: A matter of life and death. Lancet 2006, 368, 1595-1607. [CrossRef]

9. Shaw, D. The FIGO initiative for the prevention of unsafe abortion. Int. J. Gynecol. Obstet. 2010, 110, 17-19. [CrossRef] [PubMed]

10. Shaukat, S.; Kazmi, A.H. Sexually transmitted infections and syndromic management. J. Pak. Assoc. Dermatol. 2016, 25, 159-161.

11. Shaw, D. Access to sexual and reproductive health for young people: Bridging the disconnect between rights and reality. Int. J. Gynecol. Obs. 2009, 106, 132-136. [CrossRef]

12. Yao, J.; Murray, A.T.; Agadjanian, V. A geographical perspective on access to sexual and reproductive health care for women in rural Africa. Soc. Sci. Med. 2013, 96, 60-68. [CrossRef] [PubMed]

13. Müller, S.; Spencer, T.M.; Daskilewicz, K. The no-go zone: A qualitative study of access to sexual and reproductive health services for sexual and gender minority adolescents in Southern Africa. Reprod. Health 2018, 15, 12. [CrossRef] 
14. Colombini, M.; Rechel, B.; Mayhew, S.H. Access of Roma to sexual and reproductive health services: Qualitative findings from Albania, Bulgaria and Macedonia. Glob. Public Health 2012, 7, 522-534. [CrossRef]

15. World Health Organization. Responding to Community Spread of COVID-19: Interim Guidance; World Health Organization: Geneva, Switzerland, 7 March 2020.

16. Tang, K.; Gaoshan, J.; Ahonsi, B.; Ali, M.; Bonet, M.; Broutet, N.; Kara, E.; Kim, C.; Thorson, A.; Thwin, S.S. Sexual and reproductive health (SRH): A key issue in the emergency response to the coronavirus disease (COVID-19) outbreak. Reprod. Health 2020, 17, 59. [CrossRef]

17. Vora, K.S.; Saiyed, S.; Natesan, S. Impact of COVID-19 on family planning services in India. Sexual Reprod. Health Matters 2020, 28, 1785378. (In English) [CrossRef] [PubMed]

18. Nagendra, G.; Carnevale, C.; Neu, N.; Cohall, A.; Zucker, J. The potential impact and availability of sexual health services during the COVID-19 pandemic. Sex. Transm. Dis. 2020, 47, 434. [CrossRef] [PubMed]

19. Karkee, R.; Morgan, A. Providing maternal health services during the COVID-19 pandemic in Nepal. Lancet Glob. Health. 2020, 8 , 1243-1244. [CrossRef]

20. World Health Organization. Coronavirus Disease 2019 (COVID-19): Situation Report, 70; World Health Organization: Geneva, Switzerland, 2020.

21. Riley, T.; Sully, E.; Ahmed, Z.; Biddlecom, A. Estimates of the potential impact of the COVID-19 pandemic on sexual and reproductive health in low-and middle-income countries. Int. Perspect. Sex. Reprod. Health 2020, 46, 46. [CrossRef] [PubMed]

22. Graham, W.J.; Afolabi, B.; Benova, L.; Campbell, O.M.R.; Filippi, V.; Nakimuli, A.; Penn-Kekana, L.; Sharma, G.; Okomo, U.; Valongueiro, S.; et al. Protecting hard-won gains for mothers and newborns in low-income and middle-income countries in the face of COVID-19: Call for a service safety net. BMJ Glob. Health 2020, 5, 2754. [CrossRef] [PubMed]

23. Arksey, H.; O’Malley, L. Scoping studies: Towards a methodological framework. Int. J. Soc. Res. Methodol. 2005, 8, 19-32. [CrossRef]

24. Levac, D.; Colquhoun, H.; O’Brien, K.K. Scoping studies: Advancing the methodology. Implement. Sci. 2010, 5, 69. [CrossRef] [PubMed]

25. Tricco, A.C.; Lillie, E.; Zarin, W.; O’Brien, K.K.; Colquhoun, H.; Levac, D.; Moher, D.; Peters, M.D.J.; Horsley, T.; Weeks, L.; et al. PRISMA extension for scoping reviews (PRISMA-ScR): Checklist and explanation. Ann. Intern. Med. 2018, 169, 467-473. [CrossRef]

26. Joanna Briggs Institute. Systematic Review Resource Package; The Joanna Briggs Institute: Adelaide, Australia, 2015.

27. Law, M.; Stewart, D.; Letts, L.; Pollock, N.; Bosch, J.; Westmorland, M. Guidelines for Critical Review of Qualitative Studies. Master's Thesis, University Occupational Therapy Evidence-Based Practice Research Group, Hamilton, ON, Canada, 1988.

28. Tyndall, J. The AACODS Checklist Is Designed to Enable Evaluation and Critical Appraisal of Grey Literature; Flinders Academic: Adelaide, Australia, 2010.

29. Castleberry. NVivo 10 [Software Program]; Version 10; QSR International 2012: Burlington, VT, USA, 2014.

30. Moher, D.; Liberati, A.; Tetzlaff, J.; Altman, D.G. RESEARCH METHODS \& REPORTING-Preferred reporting items for systematic reviews and meta-analyses: The PRISMA statement-David Moher and colleagues introduce PRISMA, an update of the QUOROM guidelines for reporting systematic reviews and meta-analyses. Bmj (Cr)-Print 2009, 338, 332.

31. Karavadra, B.; Stockl, A.; Prosser-Snelling, E.; Simpson, P.; Morris, E. Women's perceptions of COVID-19 and their healthcare experiences: A qualitative thematic analysis of a national survey of pregnant women in the United Kingdom. BMC Pregnancy Childbirth 2020, 20, 1-8. [CrossRef] [PubMed]

32. Jacob, L.; Smith, L.; Butler, L.; Barnett, L.; Grabovac, Y.; McDermott, I.; Armstrong, D.; Yakkundi, N.; Tully, M.A. Challenges in the practice of sexual medicine in the time of COVID-19 in the United Kingdom. J. Sex. Med. 2020, 17, 1229-1236. [CrossRef] [PubMed]

33. McDonald, H.I.; Tessier, E.; White, J.M.; Woodruff, M.; Knowles, C.; Bates, C.; Parry, J.; Walker, J.L.; Scott, J.A.; Smeeth, L.; et al. Early impact of the coronavirus disease (COVID-19) pandemic and physical distancing measures on routine childhood vaccinations in England, January to April 2020. Eurosurveillance 2020, 25, 2000848.

34. Ashton, J.J.; Kammermeier, J.; Spray, C.; Russell, R.K.; Hansen, R.; Howarth, L.J.; Deb, P.; Renji, E.; Muhammed, R.; Beattie, R.M.; et al. Impact of COVID-19 on diagnosis and management of paediatric inflammatory bowel disease during lockdown: A UK nationwide study. Arch. Dis. Child. 2020, 105, 1186-1191. [CrossRef] [PubMed]

35. Torres, T.S.; Hoagland, B.; Bezerra, D.R.; Garner, A.; Jalil, E.M.; Coelho, L.E.; Benedetti, M.; Pimenta, C.; Grinsztejn, B.; Veloso, V.G. Impact of COVID-19 Pandemic on sexual minority populations in Brazil: An analysis of social/racial disparities in maintaining social distancing and a description of sexual behavior. AIDS Behav. 2020, 25, 73-84. [CrossRef] [PubMed]

36. Sanchez, T.H.; Zlotorzynska, M.; Rai, M.; Baral, S.D. Characterizing the impact of COVID-19 on men who have sex with men across the United States in April, 2020. Aids Behav. 2020, 24, 2024-2032. [CrossRef]

37. Stephenson, R.; Chavanduka, T.M.; Rosso, M.T.; Sullivan, S.P.; Pitter, R.A.; Hunter, A.S.; Rogers, E. Sex in the time of COVID-19: Results of an online survey of gay, bisexual and other men who have sex with men's experience of sex and HIV prevention during the US COVID-19 epidemic. Aids Behav. 2021, 25, 40-48. [CrossRef] [PubMed]

38. Starks, T.J.; Jones, S.S.; Sauermilch, D.; Benedict, M.; Adebayo, T.; Cain, D.; Simpson, K.N. Evaluating the impact of COVID-19: A cohort comparison study of drug use and risky sexual behavior among sexual minority men in the USA. Drug Alcohol Depend. 2020, 216, 108260. [CrossRef] 
39. Gillespie, D.; Knapper, C.; Hughes, D.; Couzens, Z.; Wood, F.; De Bruin, M.; Ma, R.; Jones, A.T.; Williams, A.; Hood, K. Early impact of COVID-19 social distancing measures on reported sexual behaviour of HIV pre-exposure prophylaxis users in Wales. Sex. Transm. Infect. 2021, 97, 85-87. [CrossRef]

40. Caruso, S.; Rapisarda, A.M.C.; Minona, P. Sexual activity and contraceptive use during social distancing and self-isolation in the COVID-19 pandemic. Eur. J. Contracept. Reprod. Health Care 2020, 25, 445-448. [CrossRef]

41. Schiavi, M.C.; Spina, V.; Zullo, M.A.; Colagiovanni, V.; Luffarelli, P.; Rago, R.; Palazzetti, P. Love in the time of COVID-19: Sexual function and quality of life analysis during the social distancing measures in a group of Italian reproductive-age women. J. Sex. Med. 2020, 17, 1407-1413. [CrossRef] [PubMed]

42. Shilo, G.; Mor, Z. COVID-19 and the Changes in the Sexual Behavior of Men Who Have Sex With Men: Results of an Online Survey. J. Sex. Med. 2020, 17, 1827-1834. (In English) [CrossRef]

43. Lehmiller, J.J.; Garcia, J.R.; Gesselman, A.N.; Mark, K.P. Less sex, but more sexual diversity: Changes in sexual behavior during the COVID-19 coronavirus pandemic. Leis. Sci. 2020, 1-10. [CrossRef]

44. Yuksel, B.; Ozgor, F. Effect of the COVID-19 pandemic on female sexual behavior. Int. J. Gynecol. Obstet. 2020, 150, 98-102. [CrossRef] [PubMed]

45. Ceulemans, M.; Verbakel, J.Y.; van Calsteren, K.; Eerdekens, A.; Allegaert, K.; Foulon, V. SARS-CoV-2 infections and impact of the COVID-19 pandemic in pregnancy and breastfeeding: Results from an observational study in primary care in Belgium. Int. J. Environ. Res. Public Health 2020, 17, 6766. [CrossRef] [PubMed]

46. Fuchs, A.; Matonóg, A.; Pilarska, J.; Sieradzka, P.; Szul, M.; Czuba, B.; Drosdzol-Cop, A. The impact of COVID- 19 on female sexual health. Int. J. Environ. Res. Public Health 2020, 17, 7152. [CrossRef] [PubMed]

47. Anja, S.; Skirrow, H.; Kampmann, B. Impact of COVID-19 on Immunization Services for Maternal and Infant Vaccines: Results of a Survey Conducted by Imprint-The Immunising Pregnant Women and Infants Network. Vaccines 2020, 8, 556.

48. Mbizvo, M.T.; Phillips, S.J. Family planning: Choices and challenges for developing countries. Best Pract. Res. Clin. Obstet. Gynaecol. 2014, 28, 931-943. [CrossRef] [PubMed]

49. Olagunju, O.S.; Bolarinwa, O.A.; Babalola, T. Social distancing, lockdown obligatory, and response satisfaction during Covid-19 pandemic: Perception of Nigerian social media users. Adv. J. Soc. Sci. 2019, 7, 44-53. [CrossRef]

50. Kates, J.; Michaud, J.; Tolbert, J. Stay-At-Home Orders to Fight COVID-19 in the United States: The Risks of a Scattershot Approach. 2020. Available online: https://www.kff.org/coronavirus-policy-watch/stay-at-home-orders-to-fight-COVID-19/ (accessed on 4 November 2020).

51. Panzeri, M.; Ferrucci, R.; Cozza, A.; Fontanesi, L. Changes in sexuality and quality of couple relationship during the Covid-19 lockdown. Front. Psychol. 2020, 11. [CrossRef] [PubMed]

52. Lyons, H.; Manning, W.; Giordano, P.; Longmore, M. Predictors of heterosexual casual sex among young adults. Arch. Sex. Behav. 2013, 42, 585-593. [CrossRef] [PubMed]

53. Yip, P.S.; Zhang, H.; Lam, T.H.; Lam, K.F.; Lee, A.M.; Chan, J.; Fan, S. Sex knowledge, attitudes, and high-risk sexual behaviors among unmarried youth in Hong Kong. BMC Public Health 2013, 13, 1-10. [CrossRef] [PubMed]

54. Lyons, H.A. Heterosexual casual sex and STI diagnosis: A latent class analysis. Int. J. Sex. Health 2017, 29, 32-47. [CrossRef] [PubMed] 